\title{
CHROMOSOMAL LOCATION OF HOR 3, A NEW LOCUS GOVERNING STORAGE PROTEINS IN BARLEY
}

\author{
P. R. SHEWRY*, R. A. FINCH†, SAROJ PARMAR*, J. FRANKLIN* AND \\ B. J. MIFLIN* \\ * Biochemistry Department, Rothamsted Experimental Station, Harpenden, Herts. \\ AL5 2JQ, U.K. † Plant Breeding Institute, Cambridge, U.K.
}

Received 11.xi.82

\section{SUMMARY}

\begin{abstract}
Hordein, the storage protein of barley grain, consists of three groups of polypeptides called B, C and D hordeins. Each group is coded for by a complex locus and these have been designated Hor 2, Hor 1 and Hor 3 respectively. Previous work has shown that Hor 1 and Hor 2 are on the short arm of chromosome 5. The results of crosses designed to evaluate the linkage relationships of Hor 3 show that it is located about $9 \mathrm{cM}$ from the centromere on the long arm of chromosome 5. The loci nec 1 and wst 5 are located $8.0 \pm 1.5$ and $37.4 \pm 4.7 \mathrm{cM}$ respectively distal to Hor 3 . These results are discussed in relation to the chromosomal location of loci which code for homologous groups of storage proteins in wheat.
\end{abstract}

\section{INTRODUCTION}

Hordein, the prolamin storage protein of barley grain, is composed of a number of polypeptides which differ in their molecular weight, charge and isoelectric point (Shewry, Ellis, Pratt and Miflin, 1978a). The "B" and "C" groups of polypeptides account for about 95 per cent of the fraction and have been purified and characterized (Shewry et al., 1980c). They differ in a number of their properties, notably their content of sulphur amino acids. We have recently purified a further group, D hordein, which consist of high molecular weight (HMW) polypeptides (apparent $M_{r}$ 105,000) (Field, et al., 1982). Furthermore we have shown that this group has properties in common with the HMW polypeptide components of wheat storage proteins (often called glutenins), notably a high content of glycine.

The numbers and electrophoretic properties of " $B$ " and " $C$ " hordein polypeptides differ between varieties (Shewry et al., 1978a; Shewry, Pratt and Miflin 1978c; Shewry et al., 1979). Genetic analysis of crosses has shown that the patterns of " $C$ " and " $B$ " hordein polypeptides are determined by separate loci, called Hor 1 and Hor 2 respectively, located on the short arm chromosome 5 (Solari and Favret, 1971; Oram, Doll and Køie, 1975; Shewry, Pratt, Finch and Miflin, 1978b; Netsvetaev, 1978; Sozinov et al., 1978; Doll and Brown, 1979; Shewry et al., 1980b; Jensen et al., 1980). This location was confirmed by Lawrence and Shepherd (1981) using addition lines of bariey into wheat. Molecular analysis of the Hor 2 locus using recombinant DNA techniques (Forde et al., 1981) and the analysis of " $\mathrm{B}$ " hordein polypeptide fragmentation patterns (Faulks, Shewry and Miflin, 1981) both suggest that the locus consists of multiple 
genes coding for two sub-families of related polypeptides, but the exact number and spatial organisation of these genes is not known.

Lawrence and Shepherd (1981) also showed that a quantitatively minor storage protein component of high molecular weight was coded for by genes on the long arm of barley chromosome 5, this location being similar to those of genes coding for the HMW glutenin polypeptides on the long arms of the homoeologous group 1 chromosomes of wheat. The properties of this component suggest that it is " $D$ " hordein and we have therefore made crosses between lines with marker genes on chromosome 5 in order to determine the exact location of the " $D$ " hordein locus, which we have called Hor 3 (Miflin and Shewry, 1981). The results of this study are reported here.

\section{MATERIALS AND METhODS}

\section{(i) Material}

Crosses were made among Hordeum vulgare L. cultivars Cambrinus, Nigrinudum and Sultan (all Plant Breeding Institute stocks) and between lines CI 2010 (Hungarian) from the World Barley Collection and S114 supplied by Dr J. Jensen of Risø National Laboratories, Roskilde, Denmark. Table 1 gives the alleles in each parent at the Hor 1, Hor 2 and Hor 3 and marker loci. Alleles at the first two loci have been named after the

TABLE 1

Genotypes of parents of the crosses

\begin{tabular}{|c|c|c|c|c|c|}
\hline \multicolumn{6}{|c|}{ Hordein alleles } \\
\hline Varieties & Hor 1 & Hor 2 & Hor 3 & & Marker loci \\
\hline Cambrinus & $\operatorname{Pr}$ & $\mathrm{Ze}$ & $\mathrm{Cb}$ & Rps 4 & \\
\hline Nigrinudum & $\mathrm{Ni}$ & $\mathrm{Ni}$ & $\mathrm{Ni}$ & & $B M \ln n$ \\
\hline Sultan & $\mathrm{Pr}$ & $\mathrm{Pr}$ & $\mathrm{Cb}$ & & \\
\hline Cl 2010 (Hungarian) & $\mathrm{Hu}$ & $\mathrm{Hu}$ & $\mathrm{Ni}$ & & {$[B]$} \\
\hline S114 & $\operatorname{Pr}$ & $\mathrm{Ze}$ & $\mathrm{Cb}$ & & nec 1 wst 5 \\
\hline
\end{tabular}

standard varieties containing them. Alleles at Hor 3 have not previously been named so we have designated the allele in Cambrinus, Sultan and $\mathrm{S} 114$ Hor $3 \mathrm{Cb}$ after Cambrinus. This allele specifies a single major band of $M_{r} 105,000$ on sodium dodecyl sulphate polyacrylamide gel electrophoresis (SDS-PAGE) as shown in fig. 1 lanes a, $c$ and e. The allele in Nigrinudum and CI 2010 (designated Hor $3 \mathrm{Ni}$ ) specifies a major band of slightly faster mobility (fig. 1 lanes b, d). The Hor 1 allele in CI 2010 (Hor $1 \mathrm{Hu}$ ) specifies a different polypeptide pattern from that of Hor $1 \mathrm{Pr}$ (Sultan, Cambrinus and S114) but these could not be differentiated by the analytical procedures used for the single seeds (fig. 1, lanes d, e).

Markers in the parents (table 1) were the dominant genes Rps 4 ( $Y r 4$ ), resistant reaction to barley yellow rust, Puccinia striiformis West race 23 but not 24 (Johnson and Finch, 1976); Mlnn (JMlnn), reaction to powdery 


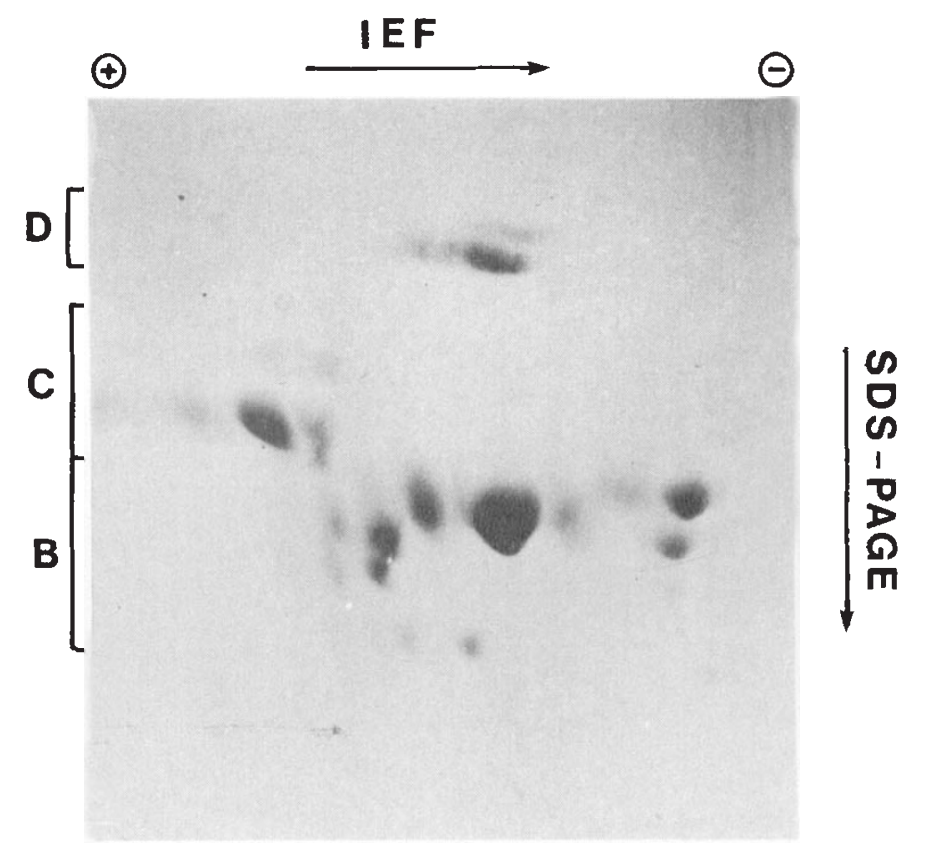

FIG. 3. Two-dimensional analysis of reduced and pyridylethylated hordein from a single $F_{2}$ seed from cross 2 (Nigrinudum $\times$ Sultan). The hordein alleles present are Hor $1 \mathrm{Ni} \mathrm{Ni}$ $\mathrm{Ni}$, Hor $2 \mathrm{Ni} \mathrm{Ni} \mathrm{Ni}$ and Hor $3 \mathrm{Ni} \mathrm{Ni} \mathrm{Cb}$. B, C and D are the groups of hordein polypeptides. The isoelectric focusing (IEF) separation was in the $p \mathrm{H}$ range 5-9. 


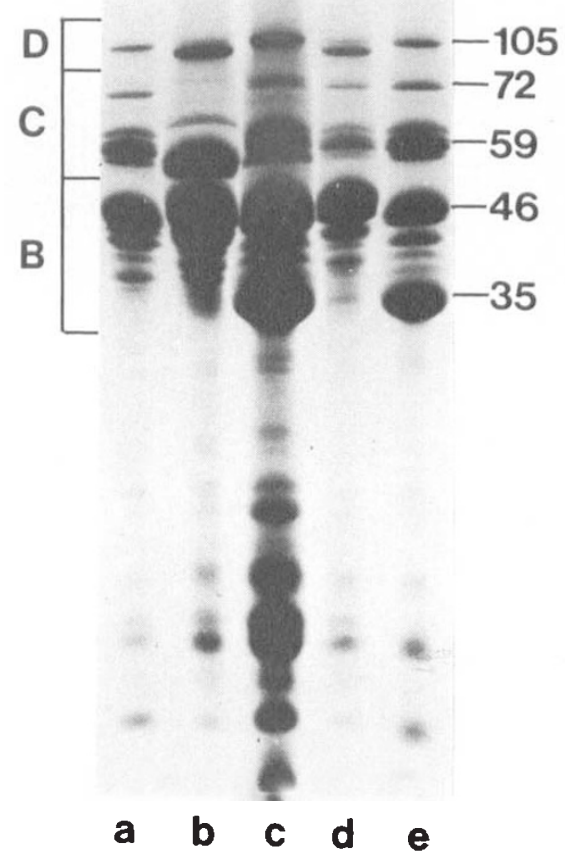

FIG. 1. SDS-PAGE of reduced and pyridylethylated hordein fractions from single seeds of the varieties used as parents in the crosses. (a) Sultan; (b) Nigrinudum; (c) Cambrinus, (d) CI 2010 (Hungarian); (e) S114, B, C and D are the groups of hordein polypeptides. Apparent molecular weights were determined in a previous study (Faulks et al., 1981). 
mildew, Erysiphe graminis DC f. sp. hordei Marchal (Hiura, 1972) and B, black lemma and pericarp (Haus and Tsuchiya, 1971); and the recessive genes nec 1, necrotic leaf spotting (Jensen, 1973) and wst5, white streaks on young leaves (Jensen, 1973). The chromosomal locations of these loci and of Hor 1 and Hor 2 are shown in fig. 2(a) which is based on Jensen (1982).

\section{Short arm Long arm}

a

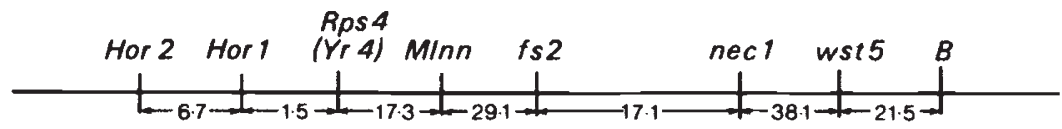

b

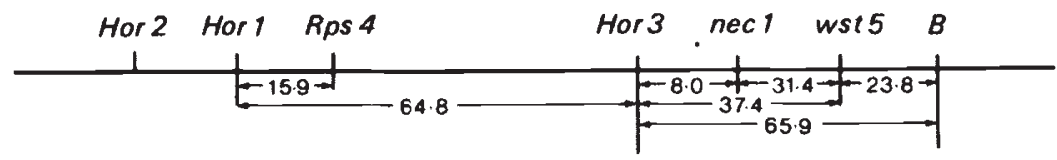

C

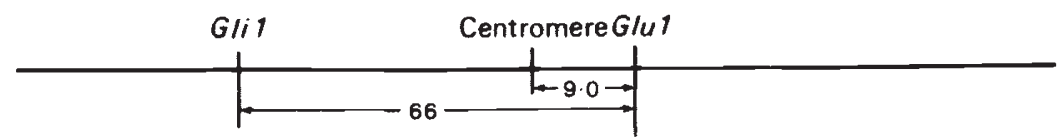

FIG. 2.(a) Part of the linkage map of chromosome 5 of barley, showing the map distances between marker loci in the parents of the crosses. The centromere is thought to be just to the left of $f s 2$. Redrawn from Jensen (1982). (b) Map distances between Hor 3 and marker loci in the parents of the crosses, based on data reported here. (c) Map distances between the loci Glu 1, Gli 1 and the centromere on the homoeologous group 1 chromosomes of wheat, based on the data of Payne et al., (1982). Map distances are in centimorgans $(\mathrm{cM})$.

Five $F_{1}$ plants of Cambrinus $\times$ Nigrinudum (cross 1) and 7 of Nigrinudum $\times$ Sultan (cross 2) were grown together in a glasshouse at the Plant Breeding Institute. In cross 1,110 bagged $F_{2}$ seeds $(21-22$ from each $F_{1}$ ) gave $109 F_{2}$ plants and $F_{3}$ families. $F_{2}$ plants were scored as seedlings for reaction to yellow rust race 24 (cross 1 only) and at maturity for lemma and pericarp colour. From each $F_{2}$ plant, separate batches of $F_{3}$ seedlings were tested for reaction to yellow rust race 23 or mildew and five $F_{3}$ seeds were scored for hordein pattern.

In cross 2,35 bagged $F_{2}$ seeds were sown from each $F_{1}, 20$ in sample $X$ and 15 in sample $Y$. Failure of germination or technique prevented scores in some cases. In sample $X$, each seed was cut in two and the embryo-bearing part sown for a mildew reaction test and the other part scored for hordein patterns. Scores were obtained from 86 plants (6-18 from each $F_{1}$ ) for reaction to mildew, 92 seeds $\left(6-19\right.$ from each $\left.F_{1}\right)$ for " $C$ " hordeins and 97 seeds $\left(6-20\right.$ from each $\left.F_{1}\right)$ for " $D$ " hordeins. In sample $Y, 50 F_{2}$ plants (3-14 from each $F_{1}$ ) were scored for lemma and pericarp colour, and from each $F_{2}$ plant, $F_{3}$ seedlings were scored for reaction to mildew and five $F_{3}$ seeds for hordein patterns. 
Two $\mathrm{F}_{1}$ plants of $\mathrm{CI} 2010 \times \mathrm{S} 114$ (cross 3 ) were grown together in a glasshouse at Rothamsted, $376 \mathrm{~F}_{2}$ seeds gave $365 \mathrm{~F}_{2}$ plants $(226$ and 139 from the two $F_{1}$ plants). $F_{2}$ plants were scored as seedlings for the nec 1 and wst 5 phenotypes. Five $F_{3}$ seeds from each $F_{2}$ plant were scored for hordein patterns.

\section{(ii) Tests for mildew and rust resistances}

In cross 1 reaction of intact first seedling leaf to Plant Breeding Institute stocks of yellow rust race 23 or 24 was scored two to three weeks after inoculation on a 0 to 4 scale. Resistant plants had only necrotic flecks or scored 0 to $1+$; susceptible plants scored $3-$ to 4 . The only intermediate was one $F_{3}$ plant which scored 2 . Nigrinudum has a recessive gene on chromosome 4 giving resistance (usually a $0,1-, 1$ or $1+$ score) to both races (Finch, Simpson and Johnson, 1978) whereas Cambrinus is resistant (usually necrotic flecks, only) to race 23 and susceptible to race 24 (Johnson and Finch, 1976). Therefore $10-12 F_{3}$ seedlings from each $F_{2}$ plant were tested with race 23 . An $F_{2}$ plant that had been susceptible to race 24 was deemed homozygous for $R p s 4$ if all its $\mathrm{F}_{3}$ progeny had only necrotic flecks and heterozygous if $7-12 \mathrm{~F}_{3}$ progeny were resistant, but not all merely with necrotic flecks. However, $F_{2}$ plants which had shown the Nigrinudum resistance to race 24 were deemed to have the $R p s 4$ allele only if 8 or more $F_{3}$ progeny showed only the necrotic reaction to race 23 . Thus $3 F_{2}$ plants each with all $12 \mathrm{~F}_{3}$ progeny resistant but 11 in each family with 0 to $1+$ scores, not merely necrotic flecks, were deemed homozygous for $r p s 4$, as were $21 \mathrm{~F}_{2}$ plants with $7-12$ susceptible $F_{3}$ progeny each.

Cambrinus has 2 genes for mildew resistance on chromosome 4 (Wiberg, 1974) and Sultan has a gene on chromosome 5 (Torp, Jensen and Jørgensen, 1978). Resistance due to Mlnn in Nigrinudum was distinguished from that due to Cambrinus and Sultan genes with Plant Breeding Institute mildew isolate number 210 which is pathogenic on all 3 varieties, especially Sultan, but also evokes a necrotic reaction in Nigrinudum, only. If an $\mathrm{F}_{2}$ plant did not show this necrotic reaction itself (cross 2 , sample $\mathrm{X}$ ), or in any of its $10-16 F_{3}$ progeny tested (cross 1 and cross 2 , sample $Y$ ), it was classed as homozygous for mlnn.

\section{(iii) Hordein pattern analysis}

Alleles at the Hor 1 and Hor 3 loci in seed from crosses 1 and 2 were determined by SDS-PAGE of reduced and pyridylethylated hordein fractions as described previously (Shewry et al., 1978b). Alleles at Hor 2 and Hor 3 in cross 3 were determined using a modification of the single seed method of Doll and Andersen (1981). A crushed seed was placed in a $1.5 \mathrm{ml}$ capped polypropylene centrifuge tube with $400 \mu \mathrm{l}$ of 50 per cent (v/v) propan-2-ol containing $41 \mathrm{mM}$ Tris and $40 \mathrm{mM}$ boric acid, $p \mathrm{H} 8 \cdot 6$, and 1 per cent $(v / v) 2$-mercaptoethanol. The tube was suspended in a sonic cleaning bath for $30 \mathrm{~min}$, centrifuged and $200 \mu \mathrm{l}$ of the supernatant decanted to a fresh tube. $3 \cdot 0 \mu$ l of redistilled 4 -vinylpyridine was added and the tube shaken for $2 \mathrm{~h}$ at $20^{\circ} \mathrm{C} .600 \mu \mathrm{l}$ of distilled water was then added and the tube placed at $4^{\circ} \mathrm{C}$ overnight. The precipitated hordein was removed by centrifugation, redissolved in $8 \mathrm{M}$ urea containing 10 per cent $(\mathrm{w} / \mathrm{v})$ 
SDS and separated by SDS-PAGE on a modified Laemmli gel (Forde et al., 1981). Two-dimensional analyses of hordein fractions from single seeds were made as described by Shewry et al. (1980b).

\section{(iv) Statistical analysis}

Gene linkage was tested for by $\chi^{2}$ tests and estimated by the method of maximum likelihood (Bailey, 1961). Map distance was calculated using the Kosambi function (Jensen and Jørgensen, 1975a). Genotype frequencies from different samples were pooled if homogeneous $(P>0.05)$ in contingency $\chi^{2}$ tests.

\section{Results}

The numbers of $F_{2}$ plants in the various genotypic classes, resulting from segregation at the loci studied, are given in tables 2-4 and the linkage $\chi^{2}$ and probability values in table 5. Although the parents in crosses 1 and 2 (Nigrinudum and Cambrinus or Sultan) have different alleles at the Hor 2 locus they could not be distinguished easily from heterozygotes by one-dimensional SDS-PAGE and so segregation at this locus was not

\section{TABLE 2}

Frequency in the progeny of cross 1 of genotypes resulting from pairwise combinations of alleles at the loci Hor 1, Hor 3, Rps4, B and Mlnn

\begin{tabular}{|c|c|c|c|c|c|c|c|c|c|}
\hline & \multirow{2}{*}{$\begin{array}{l}\text { Mlnn Minn, } \\
M \ln n \operatorname{mlnn}\end{array}$} & \multirow[b]{2}{*}{$m \ln n m \ln n$} & \multicolumn{3}{|c|}{ Hor 1} & \multicolumn{3}{|c|}{ Hor 3} & \multirow[b]{2}{*}{ Totals } \\
\hline & & & $\mathrm{NiNi}$ & $\mathrm{Ni} \mathrm{Pr}$ & $\operatorname{Pr} \operatorname{Pr}$ & $\mathrm{NiNi}$ & $\mathrm{NiCbC}$ & $\mathrm{Cb} \mathrm{Cb}$ & \\
\hline Rps 4 Rps 4 & 16 & 11 & 1 & 9 & 17 & 6 & 16 & 5 & 27 \\
\hline Rps 4 rps 4 & 34 & 24 & 10 & 40 & 8 & 16 & 22 & 20 & 58 \\
\hline rps 4 rps 4 & 12 & 12 & 22 & 2 & 0 & 10 & 10 & 4 & 24 \\
\hline$B B\}$ & 49 & 35 & 28 & 39 & 17 & 27 & 38 & 19 & 84 \\
\hline $\begin{array}{l}B b 5 \\
b b\end{array}$ & 13 & 12 & 5 & 12 & 8 & 5 & 10 & 10 & 25 \\
\hline Hor 3 & & & & & & & & & \\
\hline $\mathrm{Ni} \mathrm{Ni}$ & 16 & 16 & 14 & 12 & 6 & & & & 32 \\
\hline $\mathrm{NiCb}$ & 29 & 19 & 13 & 24 & 11 & & & & 48 \\
\hline $\mathrm{Cb} \mathrm{Cb}$ & 17 & 12 & 6 & 15 & 8 & & & & 29 \\
\hline Hor 3 & & & & & & & & & \\
\hline $\mathrm{Ni} \mathrm{Ni}$ & 16 & 17 & & & & & & & 33 \\
\hline $\mathrm{Ni} P r$ & 31 & 20 & & & & & & & 51 \\
\hline $\operatorname{Pr} \operatorname{Pr}$ & 15 & 10 & & & & & & & 25 \\
\hline Totals & 62 & 47 & 33 & 51 & 25 & 32 & 48 & 29 & 109 \\
\hline
\end{tabular}

studied. Similarly the Hor 1 alleles present in the parents of cross 3 (CI 2010 and S114) could not be distinguished and so segregation at this locus could not be scored. There was no evidence of recombination within the " $B$ " hordein or "C" hordein patterns and so Hor 1 and Hor 2 were treated as single loci with multiple alleles. SDS-PAGE (fig. 1) showed that all the parents had single major " $D$ " hordein bands. Two-dimensional separations by combined isoelectric focusing and SDS-PAGE showed that these "D" 
TABLE 3

Frequency in the progeny of cross 2 of genotypes resulting from pairwise combinations of alleles at the loci Hor 1, Hor 3, Minn and $\mathrm{B}$

\begin{tabular}{|c|c|c|c|c|c|c|}
\hline & \multicolumn{3}{|c|}{ Hor 1} & \multicolumn{3}{|c|}{ Hor 3} \\
\hline & $\mathrm{Ni} \mathbf{N i}$ & Ni Pr & $\operatorname{Pr} \operatorname{Pr}$ & $\mathrm{Ni} \mathrm{Ni}$ & $\mathrm{NiCb}$ & $\mathrm{CbCb}$ \\
\hline $\left.\begin{array}{l}\text { Cross } 2(\mathrm{X}) \\
\text { Mlnn Mlnn } \\
M \ln n \ln n\end{array}\right\}$ & 18 & 30 & 7 & 15 & 33 & 11 \\
\hline $\begin{array}{l}m \ln n \operatorname{mln} n \\
\text { Hor } 3\end{array}$ & 5 & 15 & 4 & 6 & 17 & 2 \\
\hline $\begin{array}{l}\mathrm{Ni} \mathrm{Ni} \\
\mathrm{Ni} \mathrm{Cb} \\
\mathrm{CbCb}\end{array}$ & $\begin{array}{r}4 \\
17 \\
6\end{array}$ & $\begin{array}{r}15 \\
31 \\
5\end{array}$ & $\begin{array}{l}3 \\
7 \\
4\end{array}$ & & & \\
\hline $\left.\begin{array}{l}\text { Cross } 2(Y) \\
\text { Mlnn Mlnn } \\
\text { Mlnn mlnn }\end{array}\right\}$ & 10 & 22 & 11 & 9 & 23 & 11 \\
\hline 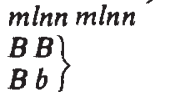 & $\begin{array}{l}1 \\
8\end{array}$ & $\begin{array}{r}5 \\
20\end{array}$ & $\begin{array}{l}1 \\
6\end{array}$ & $\begin{array}{l}0 \\
6\end{array}$ & $\begin{array}{r}6 \\
21\end{array}$ & $\begin{array}{l}1 \\
7\end{array}$ \\
\hline $\begin{array}{l}b b \\
\text { Hor } 3\end{array}$ & 3 & 7 & 6 & 3 & 8 & 5 \\
\hline $\begin{array}{l}\mathrm{Ni} \mathrm{Ni} \\
\mathrm{NiCb}\end{array}$ & $\begin{array}{l}4 \\
6\end{array}$ & $\begin{array}{r}3 \\
18\end{array}$ & $\begin{array}{l}2 \\
5\end{array}$ & & & \\
\hline $\mathrm{Cb} \mathrm{Cb}$ & 1 & 6 & 5 & & & \\
\hline
\end{tabular}

hordein bands each consisted of a number of components with different isoelectric points (fig. 3).

Segregation at the loci Hor 1, Hor 2, Hor 3 and Rps 4 gave the expected $1: 2: 1$ ratio of homozygotes:heterozygotes; homozygotes $(\boldsymbol{P}>0.05)$ in all sample populations. For Mlnn, B, wst 5 and nec1 only two phenotypic classes at each locus were scored and the expected 3 dominant: 1 recessive ratio was found in all sample populations $(P>0 \cdot 2)$ except for Mlnn in cross $1(P<0.01)$ where the ratio was apparently 9:7 $(P>0.9)$. Interactions between Mlnn and the 2 mildew resistance genes in Cambrinus may account for this exception.

The $\chi^{2}$ values indicate linkage $(P<0.05)$ between Hor 3 and the loci Hor 1 , wst 5 , nec 1 and $B$, and the recombination values are given in table 5. These data clearly show that Hor 3 is located close to nec 1 on the long arm of chromosome 5. Since the recombination percentage between nec 1 and wst $5(27 \cdot 8 \pm 2 \cdot 8)$ is less than between Hor 3 and wst $5(31 \cdot 7 \pm 2 \cdot 8)$, Hor 3 is presumed to be proximal to nec 1 . The map distances calculated from these recombination percentages are given in table 5 while a map of the locations of these loci based on these results is presented in fig. 2(b). The locus wst 5 also showed linkage with $B(22 \cdot 2 \pm 2.6$ per cent recombination). The sum of estimates of the map distances between wst 5 and $B$ and wst 5 and $H$ or $3(61.2 \mathrm{cM})$ agreed well with the distance determined between Hor 3 and $B(65.9 \mathrm{cM})$; surprisingly, nec 1 was not linked with $B$. Hor 1 showed linkage with the yellow rust resistance locus Rps 4 , although the map distance $(15.9 \pm 3.0 \mathrm{cM})$ was considerably greater than that calculated by Jensen (1982) (1.5 cM, see fig. 2(a)). Also, Rsp 4 was not apparently linked with Hor 3. A further inconsistency was that Hor 1 showed linkage 


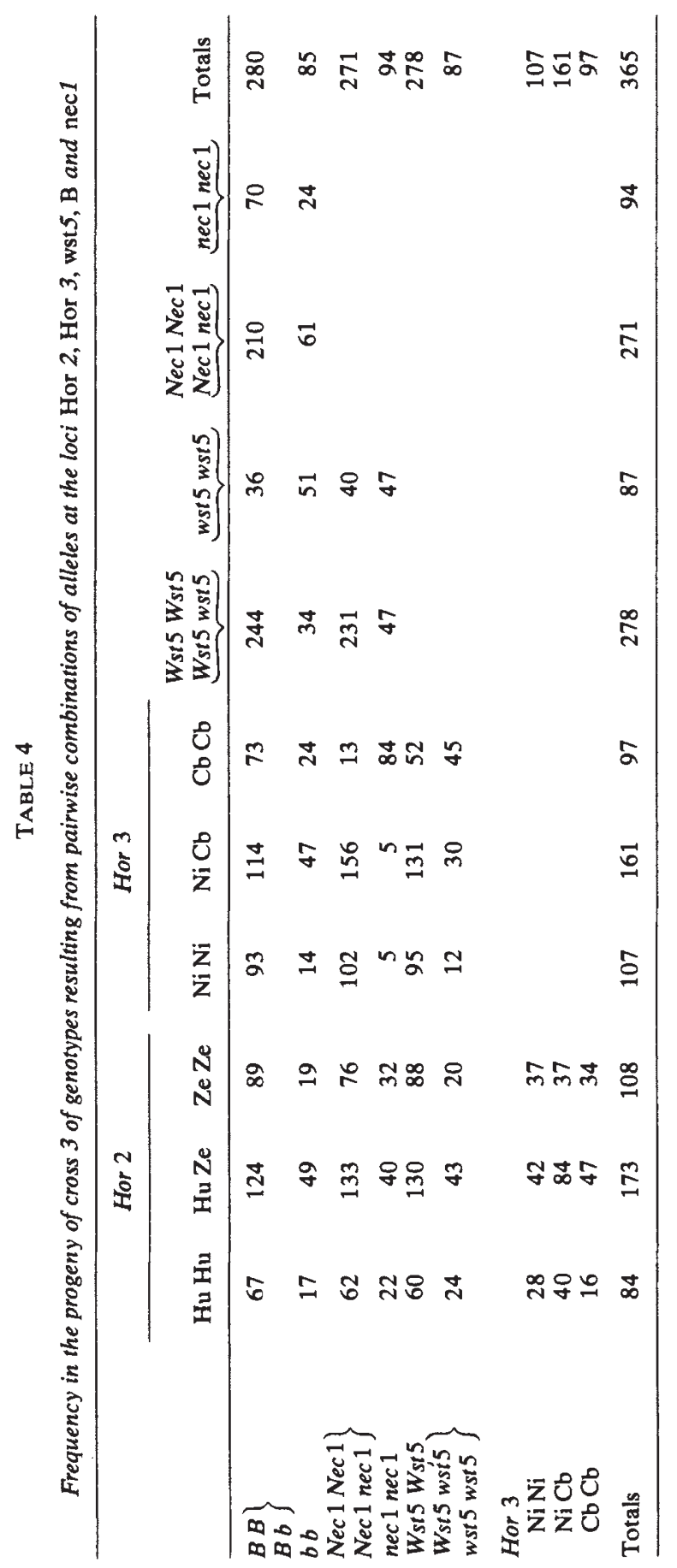


TABLE 5

Linkage $\chi^{2}$, probability values, recombination percentages and map distances for the loci segregating in crosses $1-3$

\begin{tabular}{|c|c|c|c|c|c|}
\hline Loci & Cross & $\begin{array}{l}\text { Linkage } x^{2} \\
d_{f}=1\end{array}$ & $\begin{array}{l}\text { Probability of } \\
\text { independence }\end{array}$ & $\begin{array}{l}\text { Recombination } \\
\text { percentage } \\
( \pm \text { S.E. })\end{array}$ & $\begin{array}{l}\text { Map distance } \\
\text { in cM } \\
( \pm \text { S.E. })\end{array}$ \\
\hline \multirow[t]{4}{*}{ Hor $1 \times$ Hor 3} & 1 & $3 \cdot 26$ & $<0 \cdot 1$ & $42 \cdot 0 \pm 4 \cdot 4$ & \\
\hline & $2(X)$ & $0 \cdot 07$ & $>0 \cdot 5$ & $51 \cdot 7 \pm 6 \cdot 4$ & \\
\hline & $2(\mathrm{Y})$ & 4.57 & $<0.05$ & $33 \cdot 1 \pm 6 \cdot 6$ & \\
\hline & $1+2(X+Y)$ & $4 \cdot 24$ & $<0.05$ & $43 \cdot 0 \pm 3 \cdot 3$ & $64 \cdot 8 \pm 12 \cdot 7$ \\
\hline Hor $1 \times$ Rps 4 & 1 & $70 \cdot 83$ & $<0.001$ & $15 \cdot 4 \pm 2 \cdot 7$ & $15 \cdot 9 \pm 3 \cdot 0$ \\
\hline \multirow[t]{5}{*}{ Hor $1 \times$ Mlnn } & 1 & 1.65 & $>0 \cdot 1$ & $56 \cdot 2 \pm 4 \cdot 8$ & \\
\hline & $2(X)$ & 0.51 & $>0.5$ & $45 \cdot 2 \pm 6 \cdot 7$ & \\
\hline & $2(\mathrm{Y})$ & 0.02 & $>0.9$ & $51 \cdot 5 \pm 10 \cdot 5$ & \\
\hline & $2(X+Y)$ & $0 \cdot 28$ & $>0.5$ & $47 \cdot 0 \pm 5 \cdot 6$ & \\
\hline & $1+2(X)$ & 0.40 & $>0.5$ & $52 \cdot 4 \pm 3 \cdot 9$ & \\
\hline \multirow[t]{3}{*}{ Hor $1 \times B$} & 1 & $2 \cdot 42$ & $>0 \cdot 1$ & $41 \cdot 0 \pm 5 \cdot 7$ & \\
\hline & $2(\mathrm{Y})$ & 1.57 & $>0.2$ & $39 \cdot 5 \pm 8 \cdot 1$ & \\
\hline & $1+2(Y)$ & 3.96 & $<0.05$ & $40 \cdot 5 \pm 4 \cdot 7$ & $56 \cdot 4 \pm 13 \cdot 6$ \\
\hline Hor $2 \times$ Hor 3 & 3 & 0.82 & $>0 \cdot 1$ & $52 \cdot 3 \pm 2 \cdot 5$ & \\
\hline Hor $2 \times w s t 5$ & 3 & $2 \cdot 83$ & $>0.05$ & $55 \cdot 3 \pm 3 \cdot 1$ & \\
\hline Hor $2 \times$ nec 1 & 3 & 0.45 & $>0.5$ & $47 \cdot 9 \pm 3 \cdot 1$ & \\
\hline Hor $2 \times B$ & 3 & 0.44 & $>0 \cdot 5$ & $52 \cdot 1 \pm 3 \cdot 1$ & \\
\hline Hor $3 \times w s t 5$ & 3 & $36 \cdot 2$ & $<0.001$ & $31 \cdot 7 \pm 2 \cdot 8$ & $37 \cdot 4 \pm 4 \cdot 7$ \\
\hline Hor $3 \times$ nec 1 & 3 & $238 \cdot 1$ & $<0.001$ & $7 \cdot 9 \pm 1 \cdot 5$ & $8 \cdot 0 \pm 1 \cdot 5$ \\
\hline \multirow[t]{4}{*}{ Hor $3 \times B$} & 1 & $3 \cdot 12$ & $<0 \cdot 1$ & $40 \cdot 0 \pm 5 \cdot 5$ & \\
\hline & $2(\mathrm{Y})$ & 0.45 & $>0.5$ & $44 \cdot 9 \pm 8 \cdot 7$ & \\
\hline & 3 & $4 \cdot 0$ & $<0.05$ & $44 \cdot 0 \pm 3 \cdot 0$ & $68 \cdot 9 \pm 13 \cdot 2$ \\
\hline & $1+2(Y)+3$ & $7 \cdot 01$ & $<0.01$ & $43 \cdot 3 \pm 2 \cdot 5$ & $65 \cdot 9 \pm 10 \cdot 0$ \\
\hline Hor $3 \times$ Rps 4 & 1 & 0.77 & $>0.3$ & $46 \cdot 2 \pm 4 \cdot 3$ & \\
\hline \multirow[t]{4}{*}{ Hor $3 \times M \ln n$} & 1 & 0.68 & $>0 \cdot 3$ & $53 \cdot 9 \pm 4 \cdot 7$ & \\
\hline & $2(X)$ & $0 \cdot 50$ & $>0.3$ & $54 \cdot 7 \pm 6 \cdot 6$ & \\
\hline & $2(\mathrm{Y})$ & 0.02 & $>0.8$ & $48.4 \pm 10 \cdot 9$ & \\
\hline & $2(X+Y)$ & 0.29 & $>0.5$ & $53 \cdot 0 \pm 5 \cdot 6$ & \\
\hline$R p s 4 \times M \ln n$ & 1 & $0 \cdot 21$ & $>0.5$ & $52 \cdot 3 \pm 4 \cdot 9$ & \\
\hline$B \times M \ln n$ & 1 & $0 \cdot 12$ & $>0.7$ & $47 \cdot 9 \pm 5 \cdot 8$ & \\
\hline nec $1 \times$ wst 5 & 3 & $43 \cdot 55$ & $<0.001$ & $27 \cdot 8 \pm 2 \cdot 8$ & $31 \cdot 4 \pm 4 \cdot 1$ \\
\hline nec $1 \times B$ & 3 & 0.33 & $>0.5$ & $47 \cdot 7 \pm 3 \cdot 8$ & \\
\hline wst $5 \times B$ & 3 & $71 \cdot 87$ & $<0.001$ & $22 \cdot 2 \pm 2 \cdot 6$ & $23 \cdot 8 \pm 3 \cdot 2$ \\
\hline
\end{tabular}

with $B$ when the data from crosses 1 and $2(Y)$ were combined, although not with the data from either cross alone. There was no evidence for linkage between the Nigrinudum mildew resistance gene (Mlnn) and Hor 1, Hor 3 or Rps 4 , although it would have been expected from the chromosome map of Jensen (1982) (fig. 2(a)).

\section{Discussion}

The linkage data for Hor 3 and the loci Hor 1, nec 1, wst 5 and $B$ are consistent with the location of Hor 3 about $8 \mathrm{~cm}$ to the centromere side of nec 1 , on the long arm of chromosome 5. The map distances calculated for these loci are in good agreement with the chromosome map of Jensen (1982) (fig. 2a). However, some of the other recombination frequencies are not in agreement with this map; Hor 1 and Rps 4 are $15.9 \mathrm{cM}$ apart in cross 1 but only $1.5 \mathrm{cM}$ apart in Jensen's map (fig. 2(a)), and the loose 
linkage between $H o r ~ 1$ and $B$ in crosses $1+2(\mathrm{Y})$ combined, which was only significant at a low probability $(\boldsymbol{P}>0.05)$, is clearly inconsistent with the known locations of these loci.

We have previously experienced problems in determining Rps 4 ( $Y r 4$ ) (Shewry et al., 1980b) but we do not think these were responsible for the results in the present study, however; Jensen (1982) has noted that the proposed position (fig. 2(a)) of this locus is not certain. Why Mlnn shows no linkage with any of the other loci is not known. The location of this gene on chromosome 5 is based only on a loose linkage with nec 1 (36.8 $4 \cdot 2)$ reported by Jensen and Jørgensen (1975b). It may be that $M \ln n$ is not actually located within the map shown in fig. $2(a)$, but this requires confirmation.

It is of interest to compare the locations of the loci coding for hordein polypeptides with those coding for related proteins present in wheat and rye (Miflin, Field and Shewry, 1983). The HMW components of wheat, which are homologous with "D" hordein, are coded for by alleles at Glu 1 which have been mapped $9 \mathrm{cM}$ from the centromeres on the long arms of the homoeologous group 1 chromosomes (Payne et al., 1982) (fig. 2(c)). The centromere of barley chromosome 5 is thought to be located just on the short arm side of $f s 2$ which would place $H o r ~ 3$ about $9 \mathrm{~cm}$ from the centromere in a similar position to Glu 1 . The $\omega$-gliadins of wheat are homologus with " $C$ " hordein (Shewry, Autran, Nimmo, Lew and Kasarda, $1980 \mathrm{a}$ ) and these are coded for by alleles at $G l i 1$, which are located at $66 \mathrm{CM}$ from Glu 1 on the short arms of the same chromosomes (Payne $e t$ al., 1982) (fig. 2(c)). This distance is strikingly similar to that between Hor 1 and Hor $3(64.8 \pm 3.3 \mathrm{cM})$. The $\gamma$-gliadins of wheat have similar amino acid compositions to "B" hordein but are also coded for by Gli 1 alleles (Sosinov and Poperelya, 1980) which may indicate that Gli 1 of wheat is equivalent to Hor 1 and Hor 2 of barley. Rye has genes coding for low and high molecular weight prolamins on the short and long arms respectively of chromosome 1R (Lawrence and Shepherd, 1981). Other wheat gliadins are coded for by alleles at loci (provisionally called Gli 2) on the short arms of the group 6 chromosomes (Payne et al., 1982). These loci appear to be absent from barley and rye.

During the completion of this study we became aware of a similar study of the location of the genes for " $D$ " hordein by Blake, Ullrich and Nilan (1982). However their results showed that the controlling locus was only about $35 \mathrm{cM}$ from $H o r$, which would place it on the short arm or, in the centromeric region. This is not consistent with the results reported here.

Acknowledgements. We are grateful to Drs J. Jensen and H. Doll (Risø National Laboratory, Roskilde, Denmark) for helpful discussions and for critical comments on this manuscript. Dr J. Jensen also supplied seed of S114. We are also grateful to Dr P. I. Payne (PBI, Cambridge) for making available a reprint of his manuscript and Ms A. J. Faulks for running the two-dimensional gel showing in fig. 3 .

\section{REFERENCES}

BAlLEY, N. T. J. 1961. Introduction to the Mathematical Theory of Linkage. Oxford University Press.

BLAKE, T. K, ULLRICH, S. E. AND NILAN, R. A. 1982. Mapping of the Hor 3 locus encoding

"D" hordeins in barley. Theor. Appl. Genet. 63, 367-371. 
DOLl, H. AND ANDERSEN, B. 1981. Preparation of barley storage protein, hordein, for analytical sodium dodecyl sulphate-polyacrylamide gel electrophoresis. Anal. Biochem., $115,61-66$.

DOLL, H. AND BROWN, A. D. H. 1979. Hordein variation in wild (Hordeum spontaneum) and cultivated (H. vulgare) barley. Can. J. Genet. Cytol., 21, 391-404.

FAULKS, A. J. SHEWRY, P. R. AND MIFLIN, B. J. 1981. The polymorphism and structural homology of storage polypeptides (hordein) coded by the Hor 2 locus in barley (Hordeum vulgare L.). Biochem. Genet., 19, 841-858.

FIELD, J. M., SHEWRY, P. R., MIFLIN, B. J. AND MARCH, J. F. 1982. The purification and characterization of homologous high molecular weight storage proteins from the grain of wheat rye and barley. Theor. appl. Genet., 62, 329-336.

FINCH, R. A., SIMPSON, E. AND JOHNSON, R, 1978. Ethiopian barleys with resistance to yellow rust (Puccinia striformis West) and brown rust (P. hordei Otth.). Barley Newsl., $21,56-57$.

FORDE, B. G., KREIS, M., BAHRAMIAN, M. B., MATTHEWS, J. A., MIFLIN, B. J., THOMPSON, R. D., BARTELS, D. AND FLA VELL, R, B. 1981. Molecular cloning and analysis of cDNA sequences derived from poly $\mathrm{A}^{+}$RNA from barley endosperm: identification of $\mathrm{B}$ hordein related clones. Nucleic Acids Research, 9, 6689-6707.

HAUS, T. E. AND TSUCHIYA, T. 1971. Black lemma and pericarp. Barley Genet. Newsl., 1, 148. HIURA, U. 1972. Mildew resistance. Barley Genet. Newsl., 2, 194.

JENSEN, J. 1973. Locating some genes on barley chromosome 5. Barley Genetics Newsl., 3, 25-27.

JENSEN, J. 1982. Coordinators Report: Chromosome 5. Barley Genetics Newsl., 12, 87-90. JENSEN, J. AND JøRGENSEN, J. H. 1975a. The barley chromosome 5 linkage map. I. Literature survey and map estimation procedure. Hereditas, 80, 5-16.

JENSEN, J. AND JøRGENSEN, J, H, 1975b. The barley chromosome 5 linkage map. II. Extension of the map with four loci. Hereditas, 80, 17-26.

JENSEN, J., JøRGENSEN, J. H., JENSEN, H. P., GIESE, H. AND DOLL, H. 1980. Linkage of the hordein loci Hor 1 and Hor 2 with the powdery mildew resistance loci $M 1-k$ and $M 1-a$ on barley chromosome 5. Theor. appl. Genet., 58, 27-31.

JOHNSON, R. AND FINCH, R. A, 1976. Resistant to Puccinia striiformis West (stripe rust), Barley Genetics Newsl., 6, 130.

LAWRENCE, G. J. AND SHEPHERD, K. W. 1981. Chromosomal location of genes controlling seed proteins in species related to wheat. Theor. appl. Genet., 59, 25-31.

MIFLIN, B. J., FIELD, J. M. AND SHEWRY, P. R. 1983. Cereal storage proteins and their effects on technological properties. In J. Daussant, J. Mosse \& J. Vaughan (eds.) Seed Proteins, Academic Press, London. In press.

MIFLIN, B. J. AND SHEWRY, P. R. 1981. The genes for the storage proteins of barley. Abs XIII int. Bot. Congress, Australia, 1981.

NETSVETAEV, V. P. 1978. (The author's translation of) Mapping of loci Hrd in chromosome 5 of barley with the help of reciprocal translocations. Biologischeskie Osmovy Ratseonalnogo Ispolzovaniya Jivotnogo i Rastitelnogo Myra, USSR, Riga, "Zinatne", 1978, pp. $145-146$.

ORAM, R. N., DOLL, H. AND KøIE, B. 1975. Genetics of two storage protein variants in barley. Hereditas, 80, 53-58.

PAYNE, P. I., HOLT, L. M., WORLAND, A. J. AND LAW, C, N. 1982. Structural and genetical studies on the high-molecular-weight subunits of wheat glutenin Part 3. Telocentric mapping of the subunit genes on the long arms of the homoeologous group 1 chromosomes. Theor. appl. Genet., 63, 129-138.

SHEWRY, P. R., ELLIS, J. R. S., PRATT, H. M. AND MIFLIN, B. J. 1978a. A comparison of methods for the extraction and separation of hordein fractions from 29 barley varieties. J. Sci. Fd. Agr., 29, 433-441.

SHEWRY, P. R., PRATT, H. M. FINCH, R, A. AND MIFLIN, B. J. 1978b. Genetic analysis of hordein polypeptides from single seeds of barley. Heredity, 40, 463-466.

SHEWRY, P. R., PRATT, H. M. AND MIFLIN, B. J. 1978c. Varietal identification of single seeds of barley by analysis of hordein polypeptides. J. Sci. Fd. Agr., 29, 587-596.

SHEWRY, P. R., PRATT, H. M., FAUlKS, A. J., PARMAR, S. AND MIFLIN, B. J. 1979. The storage protein (hordein) polypeptide pattern of barley (Hordeum vulgare L.) in relation to varietal identification and disease resistance. J. natn. Inst. agric. Bot., 15, 34-50.

SHEWRY, P. R., AUTRAN, J-C., NIMMO, C. C., LEW, E. J-L. AND KASARDA, D. D. $1980 a$. $\mathrm{N}$-terminal amino acid sequence homology of storage protein components from barley and a diploid wheat. Nature, Lond., 286, 520-522. 
SHEWRY, P. R., FAULKS, A. J., PICKERING, R. A., JONES, I. T., FINCH, R. A. AND MIFLIN, B. J. $1980 \mathrm{~b}$. The genetic analysis of barley storage proteins. Heredity, 44, 383-389.

SHEWRY, P. R., FIELD, J. M., KIRKMAN, M. A., FAULKS, A. J. AND MIFLIN, B. J. (1980c) The extraction, solubility and characterization of two groups of barley storage polypeptides. J. Exp. Bot., 31, 393-407.

SOLARI, R. M. AND FAVET, E. A. 1971. Polymorphism in endosperm proteins of barley and its genetic control. In R. Nilan (ed.) Barley Genetics II Washington University Press, Pullman, WA, USA. pp. 23-31.

SOZINOV, A. A., NETSVETAEV, V. P., GRIGORYAN, E. M. AND OBRAZTSOV, I. S. 1978. Mapping of Hrd locuses in barley (Hordeum vulgare L. emed. Vav et Bacht). Genetika, 14, 1610-1619 (translated into English in Soviet Genetics, 1979, 14, 1137-1147).

SOZINOV, A. A. AND POPERELYA, F. A. 1980. Genetic classification of prolamines and its use for plant breeding. Ann. Technol. agric., 29, 229-245.

TORP, J., JENSEN, J. P. AND JØRGENSEN, J. 1978. Powdery mildew resistance genes in 106 northwest European spring barley varieties. Arsskr. K. Vet.-LandbKøjsk, 75-102.

WibERG, A. 1974. Sources of resistance to powdery mildew in barley. Hereditas, 78, 1-40. 